ScIDice

\section{A Systematic Review Of Three Decades Of Prevalence Of Oral Soft Tissue Infections And Conditions Among Adult HIV Patients in India}

Research Article

Shrikanth Muralidharan ${ }^{1 *}$, Arunkumar Acharya ${ }^{2}$, Pramila Mallaiah ${ }^{3}$, Shanthi Margabandhu ${ }^{4}$

${ }^{1}$ Reader, Department of Public Health Dentistry, Madha Dental College, India.

${ }^{2}$ Professor and Head, Department of Public Health Dentistry, Navodaya Dental College and Hospital, Raichur, India.

${ }^{3}$ Professor and Head, Department of Public Health Dentistry, MR Ambedkar Dental College and Hospital, Bangalore, Karnataka, India.

${ }^{4}$ Public Health Dentist, Private Practitioner, Bangalore, Karnataka, India.

\title{
Abstract
}

Oral lesions are a cue for decreased immunity among HIV positive patients. There is no cumulative data available related to the prevalence of oral soft tissue lesions among the HIV positive patients. Hence the present review was carried out to assess the various oral lesions reported among adult HIV patients across India. Two search engines were used- Google Scholar and PubMed, with key words of HIV/AIDS, Soft tissue, oral cavity, India, adults for searching the articles from January 1990 to December 2019. After initial review, 21 articles that fulfilled the criteria were included in the review. We used 9 parameters to access the quality of the reports. Most common lesion reported was that of oral candidiasis. Not all articles reported about sample size determination or of sampling design and technique. Other lesions like hyperpigmentation, gingivitis and periodontitis were also found to be highly prevalent. Most reports were from South India. Further epidemiological data is required from different regions for using it to develop planning and execution related to oral health care for the HIV positive patients in India.

Keywords: HIV; Oral Cavity; Infections; Periodontitis; Oral Mucosa; India.

\section{Introduction}

Oral lesions are a frequent finding and present early stages of decreased immunity in HIV positive individuals. This serves as a cue for further evaluation needed to underline the depleting immunity. Thus the mouth not only serves as an indicator but also reflects the response to the treatment being provided. Most of the lesions associated with HIV are found even in individuals with compromised immunity due to other reasons (like on steroids or in diabetes mellitus) but certain lesions are characteristic hall marks of HIV/AIDS. [1-4] There is still uncertainty with regards to the exact mechanism of how HIV infection may affect the oral cavity at large. HIV is majorly spread due to the mucosal surface response of the host, which when compromised assists in acquisition and rapid spread of the virus. A breakdown of the same barrier can serve dual purposes of facilitating the spread as well as translocating the microbial products for further infection and inflammation. It is suggested though that, as a response to the infection, the immunological changes alters the physical barriers in the oral cavity also and assists in further destruction.5 It also serves as a reservoir for further spread in the form of bacteraemia and septicaemia. The EEC Clearing house classification provided the common manifestation of oral lesions in HIV affected individuals. [1] Multiple studies in literature have reported the oral side effects of HIV as well as that of ART drugs which includes erythema multiforme, hyperpigmentation, xerostomia, parotid lipomatosis, cheilitis, perioral parathesis, taste alterations, facial oedema and ulcers. [6-11] Thus oral cavity in the literal sense serves as a mirror of systemic health and conditions. There is no data reported till now on the epidemiology of oral lesions and HIV across India. This s review paper brings forward a systematic view of the papers reported in dental literature regarding the prevalence of various lesions across Indian HIV population.

\section{Materials and Method}

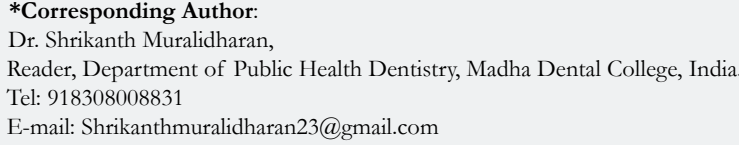

Citation: Shrikanth Muralidharan, Arunkumar Acharya, Pramila Mallaiah, Shanthi Margabandhu. A Systematic Review Of Three Decades Of Prevalence Of Oral Soft Tissue Infections And Conditions Among Adult HIV Patients in India. Int J Dentistry Oral Sci. 2021;8(10):4774-4778. doi: http://dx.doi.org/10.19070/2377-8075-21000968

Copyright: Shrikanth Muralidharan ${ }^{\circ} 2021$. This is an open-access article distributed under the terms of the Creative Commons Attribution License, which permits unrestricted use, distribution and reproduction in any medium, provided the original author and source are credited. 
We carried out a literature search using PubMed and Google scholar to access articles from January 1990 to December 2019. All freely available full text articles were selected. The key words used for searching the articles were- India, HIV, AIDS, Soft tissue, oral cavity. The inclusion criteria were-

1. All Indian based studies, reporting epidemiological data related to HIV and oral soft tissues diseases or conditions

2. All participants on ART

The initial review was done by the first author based on the title and the abstract. Later a full text review was done for the entire article. The search overall revealed 21 articles that were found eligible. The data extraction was done by the first author based on the following 09 criteria for qualitative assessment of the articles-

1. Study setting-College, hospital, NGO, home or any other place.

2. Aim and objectives clearly mentioned.

3. Sample size Formula and estimation process clearly stated.

4. Sample design mentioned which type of sampling design was followed.

5. Criteria/index used for recording.

6. Calibration of the examiners with the Kappa statistics for reliability and validity.

7. Clearly stated if generalizability is possible or not. If not, stated reasons for the same.

8. Clearly mentioned if the participants were on ART/HAART or just positive.

9. Clearly stated the inclusion and exclusion criteria.

After data extraction, all the 21 articles were independently reviewed by the rest of the authors and any discrepancy was solved by discussion and by generating a common consensus. The PRISMA guidelines was followed for reporting (Figure 01). The entire process of review and report generation was done in one month (January 2020).

\section{Results}

Of the 21 articles found eligible for study, majority were from the South part of the country. All the studies focussed on the presence of oral candidiasis except for the study by Krishna et al. [12]
For the ease of reporting, we have not classified the candidiasis, but presented the overall percentage. We also classified any form of gingivitis (either bleeding on probing, de-squamative gingivitis and liner erythema gingivitis) as one category of gingivitis. Any such form of periodontitis was also considered under periodontitis.

Most of the studies were reports by dental specialists only. Two studies $[13,14]$ reported oral manifestations as a part of the general physical examination. They were not exclusively concentrating on the oral lesions only. Kumar et al focussed only on oral candidiasis and no other oral lesions as such.[15] Only one study among the 21 reported that soft tissue lesions have no co relation with CD4 count or with ART therapy duration. [16] Rest of the studies reported of an inverse relationship between the CD4 count and the oral manifestations. Hence considering local factors like plaque and oral hygiene practices along with medications apart from ART/HAART should be taken into consideration (Table 01).

Quality assessment of the articles:

The above mentioned 09 parameters were used for quality assessment of the articles (Table 02).

Extrapolation of the data was mentioned by only 2 studies. [16, 22] The most common classification scale used was of the EC clearinghouse for soft tissue manifestation of HIV/AIDS and that by the World Health Organization Oral health Assessment 1997. Studies by Annapurna, [22] Krishna, [12] Muralidharan [16] and Dongade [30] only reported of sample size estimation and the way the samples were calculated. Even though we did not develop a scoring or a rating scale for the studies, overall quality development suggests poor patterns of reporting or at times selective reporting of the data. Not all studies have reported of periodontitis and gingivitis while reporting the lesions. Hence a major part of the information that can be useful for planning and execution is missing with the studies.

\section{Discussion}

Unlike the west, we don't have a fixed pattern of assessment and reporting of data. All authors have used different standardized

Figure 1. Search strategy.

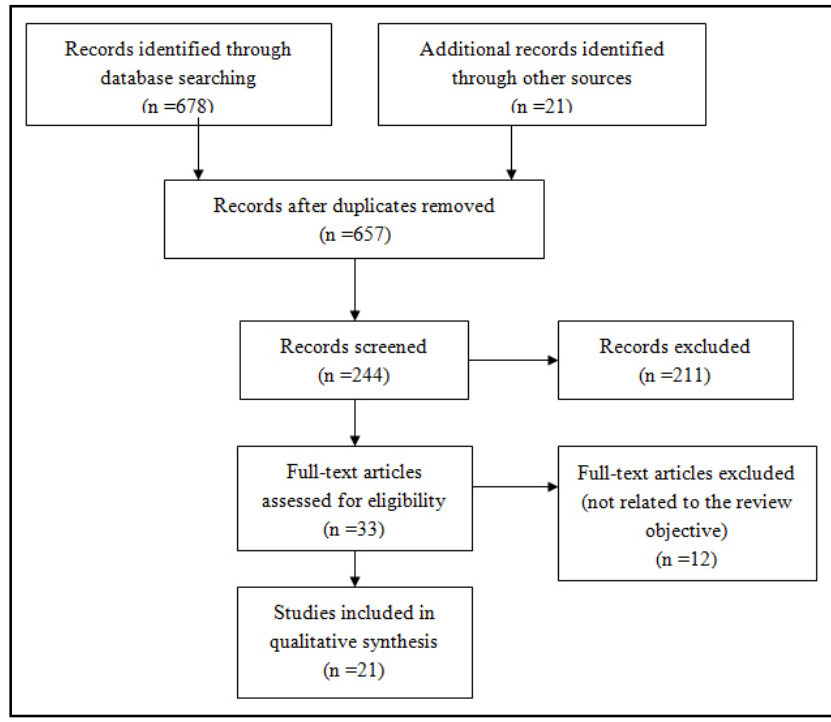


Table 1. List of research work selected for systematic review.

\begin{tabular}{|c|c|c|c|c|c|c|}
\hline S.No & Author & Year & Place & Samples & Major findings & Outcome/ Conclusion \\
\hline 1. & $\begin{array}{l}\text { Panda et } \\
\text { al17 }\end{array}$ & 1992 & Manipur & 131 & $\begin{array}{c}20.61 \% \text { - Herpes } \\
5.34 \% \text { - Oral thrush } \\
10.68 \% \text { - pruritic papular eruptions }\end{array}$ & $\begin{array}{c}\text { "Oral thrush, Herpes zoster and pruritic papular eruptions showed a high } \\
\text { specificity and positive predictive value for HIV among intravenous drug } \\
\text { users". }\end{array}$ \\
\hline 2. & $\begin{array}{c}\text { Chakraborty } \\
\text { et al13 }\end{array}$ & 2008 & Kolkata & $\begin{array}{l}125 \text { (not specified } \\
\text { as under ART) }\end{array}$ & $88 \%$ - Oral candidiasis & $\begin{array}{c}\text { "opportunistic infections showed an inverse relationship to the CD4 } \\
\text { counts" }\end{array}$ \\
\hline 3. & $\begin{array}{l}\text { Gnanasund- } \\
\quad \text { aram } 7\end{array}$ & 2010 & $\begin{array}{c}\text { Chennai, } \\
\text { Tamil } \\
\text { Nadu }\end{array}$ & $\begin{array}{l}686 \text { (not specified } \\
\text { as to ART) }\end{array}$ & $\begin{array}{l}\text { 51.5\%- oral candidiasis, } \\
\text { 10.5\% Gingivitis, } \\
\text { 8.8\%- Hairy leukoplakia, } \\
5.4 \% \text { - Oral ulcers }\end{array}$ & $\begin{array}{l}\text { "Careful examination of oral cavity will help to detect these oral man- } \\
\text { ifestations so as a clinician can identify aids in the body through oral } \\
\text { manifestation" }\end{array}$ \\
\hline 4. & $\begin{array}{l}\text { Shrimali } \\
\text { L } 18\end{array}$ & 2010 & $\begin{array}{l}\text { Not } \\
\text { men- } \\
\text { tioned }\end{array}$ & $\begin{array}{l}50 \text { (not specified } \\
\text { as to ART) }\end{array}$ & $\begin{array}{c}100 \% \text { - periodontal disease, } \\
72 \% \text { - oral candidiasis, } \\
32 \% \text { - xerostomia, } \\
42 \% \text { - lymphadenopathy, } \\
36 \% \text { - angular cheilitis } \\
22 \% \text { - persistent oral ulceration } \\
2 \% \text { - oral hairy leukoplakia } 8 \% \text { - herpes zoster, } \\
10 \% \text {-parotomegaly } \\
8 \% \text { - facial palsy } \\
\end{array}$ & $\begin{array}{c}\text { "For reducing morbidity from HIV, early detection is necessary, therefore } \\
\text { physicians must look for oral manifestation in suspected cases of HIV } \\
\text { which aid in early diagnosis and treatment" }\end{array}$ \\
\hline 5. & Saha et al14 & 2011 & Kolkata & $\begin{array}{l}204 \text { (not specified } \\
\text { as under ART) }\end{array}$ & $53.4 \%$ - Oral candidiasis & $\begin{array}{l}\text { "patients who presented HIV associated oral candidiasis without any type } \\
\text { of Anti-Retroviral Therapy (ART) had a median CD4+ count lower than } \\
200 \text { cells/mm3, an associated inverse relationship between CD4+ count } \\
\text { and the prevalence of OC could be inferred" }\end{array}$ \\
\hline 6. & $\begin{array}{l}\text { Bodhade et } \\
\quad \text { al } 19\end{array}$ & 2011 & $\begin{array}{l}\text { Nagpur, } \\
\text { Maha- } \\
\text { rashtra }\end{array}$ & 399 (not on ART) & $\begin{array}{c}\text { 39.3\%- Oral candidiasis } \\
19.5 \% \text { - hyperpigmentation } \\
11.5 \% \text { - Oral hairy leukoplakia } \\
8.5 \% \text { - Necrotizing gingivitis } \\
5.3 \% \text { - Necrotizing periodontitis } \\
\end{array}$ & $\begin{array}{l}\text { "Oral manifestations may be used as an alternative to } \mathrm{CD} 4 \text { count at field- } \\
\text { based settings to diagnose the immune compromised status of HIV-in- } \\
\text { fected individuals." }\end{array}$ \\
\hline 7. & $\begin{array}{l}\text { Hegde et } \\
\text { al20 }\end{array}$ & 2012 & $\begin{array}{l}\text { Man- } \\
\text { galore, } \\
\text { Karna- } \\
\text { taka }\end{array}$ & $\begin{array}{l}125 \text { (not specified } \\
\text { as to ART) }\end{array}$ & $\begin{array}{c}52 \% \text { - periodontitis } \\
32.8 \% \text { - Hyperpigmentation } \\
15.2 \% \text {-Oral hairy leukoplakia } \\
16.8 \% \text { - linear gingival erythema } \\
12.8 \% \text { - Angular chelitis }\end{array}$ & $\begin{array}{l}\text { "oral lesions have been found to be associated with the early manifestation } \\
\text { of HIV and a measure of disease severity" }\end{array}$ \\
\hline 8. & Rao et al21 & 2012 & $\begin{array}{c}\text { Chennai, } \\
\text { South } \\
\text { India }\end{array}$ & $\begin{array}{c}3729(71 \% \text { males } \\
\text { and } 29 \%) \text { females }\end{array}$ & $\begin{array}{l}18.8 \% \text { males and } 10.3 \% \text { in females- oral candidiasis } \\
1.2 \% \text { males and } 0.4 \% \text { females- oral hairy leukoplakia }\end{array}$ & $\begin{array}{l}\text { "Males had a higher risk of oral lesions, especially OC and OHL, than } \\
\text { females. This different immunological status of the females compared to } \\
\text { males should be taken in to consideration in the evaluation and manage- } \\
\text { ment of HIV positive patients in our country." }\end{array}$ \\
\hline 9. & $\begin{array}{l}\text { Annapurna } \\
\text { et al } 22\end{array}$ & 2012 & $\begin{array}{l}\text { Tamil } \\
\text { Nadu }\end{array}$ & 50 on ART & $\begin{array}{c}54 \% \text { - Candidiasis } \\
28 \%-\text { melanotic pigmentation } \\
6 \% \text { - Oral ulcers } \\
4 \% \text { - herpes Zooster } \\
2 \% \text { - Oral hairy leukoplakia } \\
2 \% \text { - Squamous Cell carcinoma } \\
\end{array}$ & $\begin{array}{l}\text { "Clinical stage } \mathrm{C} \text { and lower } \mathrm{CD} 4 \text { count may be useful predictors for HIV, } \\
\text { with greater prevalence of oral manifestations" }\end{array}$ \\
\hline 10. & $\begin{array}{l}\text { Jindwani et } \\
\text { al23 }\end{array}$ & 2013 & $\begin{array}{l}\text { Central } \\
\text { India, } \\
\text { MP }\end{array}$ & $\begin{array}{l}514 \text { patients on } \\
\text { ART }\end{array}$ & $\begin{array}{c}41.5 \% \text { - Oral candidiasis } \\
23.15 \% \text { - Linear gingival erythema } \\
14 \% \text { - oral hairy leukoplakia } \\
4.8 \% \text { - necrotising ulcerative gingivitis and periodontitis } \\
\text { Ulceration (atypical)- } 4.47 \% \\
\end{array}$ & $\begin{array}{l}\text { "usefulness of orofacial examination of the patients by collaborative effort } \\
\text { of dental surgeons and physicians and increases their index of suspicion } \\
\text { of the infection with the appearance of these HIV associated oral lesions" }\end{array}$ \\
\hline 11. & $\begin{array}{l}\text { Kumar et } \\
\text { al } 15\end{array}$ & 2013 & $\begin{array}{c}\text { Karna- } \\
\text { taka }\end{array}$ & $\begin{array}{l}1063 \text { patients (on } \\
\text { HAART) }\end{array}$ & $2.35 \%-$ Oral candidiasis & $\begin{array}{l}\text { "CD4 count is likely to prove and expressed the opportunistic infections } \\
\text { and Oral candidiasis. Early inception of HAART, Good ARV drug adher- } \\
\text { ence can reduce the incidence rate." }\end{array}$ \\
\hline 12. & $\begin{array}{c}\text { Kumar et } \\
\text { al } 24\end{array}$ & 2014 & $\begin{array}{l}\text { Ujiain, } \\
\text { North } \\
\text { India }\end{array}$ & 126 on ART & $\begin{array}{l}\text { Candidiasis- } 36.5 \% \\
\text { Ulceration- }-11.9 \% \\
\text { Leukoplakia- } 9.8 \% \\
\text { Malignant tumour- } 4.76 \%\end{array}$ & $\begin{array}{l}\text { "The study shows that HIV positive patients have poor oral health } \\
\text { status compared to the HIV negative individuals. Majority of the people } \\
\text { living with HIV belong to lower socioeconomic status and also have } \\
\text { less awareness about oral health. The use of antiretroviral drugs further } \\
\text { depletes their oral health and is responsible for development of oro } \\
\text { mucosal lesions" }\end{array}$ \\
\hline 13. & $\begin{array}{l}\text { Sanadhya et } \\
\text { al25 }\end{array}$ & 2014 & Rajasthan & $\begin{array}{l}232 \text { (not specified } \\
\text { as under ART) }\end{array}$ & $\begin{array}{c}26.3 \% \text { - Oral candidiasis } \\
24.6 \% \text { - Oral hairy leukoplakia } \\
22.4 \%-\text { melanotic hyperpigmentation } \\
21.1 \% \text { - Linear gingival erythema }\end{array}$ & $\begin{array}{l}\text { "The results indicated that among the patients being } \\
\text { infected with HIV, there exists a relationship between the occurrence of } \\
\text { oral lesions and oral lesions. So, diagnosis of oral lesions is of utmost } \\
\text { importance to help identify the underlying or predisposing diseases" }\end{array}$ \\
\hline 14. & Ravi et al 26 & 2015 & $\begin{array}{c}\text { Karna- } \\
\text { taka }\end{array}$ & 72 & $\begin{array}{l}46 \% \text { - oral candidiasis } \\
36.11 \% \text { - periodontitis }\end{array}$ & $\begin{array}{l}\text { "oral manifestation especially candidiasis may have important diagnostic } \\
\text { and prognostic value and belong to the earliest clinical features of the } \\
\text { infection and could predict progression of HIV to AIDS" }\end{array}$ \\
\hline 15. & $\begin{array}{l}\text { Krishna et } \\
\text { al12 }\end{array}$ & 2015 & $\begin{array}{l}\text { Hyder- } \\
\text { abad }\end{array}$ & $\begin{array}{l}200 \text { (not specified } \\
\text { as to ART) }\end{array}$ & More cases of depappilation and hyperpigmentation & $\begin{array}{l}\text { "In HIV/AIDS patients as the condition progresses, virus further weakens } \\
\text { the immune system leading to multiple oral manifestations and an increase } \\
\text { in susceptibility to severe infections and diseases causing failure of organ } \\
\text { function leading to comorbid conditions." }\end{array}$ \\
\hline 16. & Patil et al 27 & 2015 & $\begin{array}{l}\text { North } \\
\text { Karna- } \\
\text { taka }\end{array}$ & $\begin{array}{l}50 \text { on HAART } \\
\text { and } 50 \text { not on } \\
\text { HAART }\end{array}$ & $\begin{array}{c}14 \% \text { - oral pigmentation } \\
8 \% \text { - apthous stomatitis } \\
4 \% \text { - non-specific ulcerations } \\
2 \% \text { - candidiasis, xerostomia and periodontitis } \\
\end{array}$ & "Number and severity of oral lesions decreased due to HAART" \\
\hline 17. & $\begin{array}{l}\text { Hegde et } \\
\text { al28 }\end{array}$ & 2016 & $\begin{array}{c}\text { Man- } \\
\text { galore, } \\
\text { Karna- } \\
\text { taka }\end{array}$ & $\begin{array}{l}112 \text { patients on } \\
\text { ART }\end{array}$ & $\begin{array}{l}12.5 \% \text { - hyperpigmentation } \\
3.6 \% \text { - herpes simplex and lichen planus } \\
1.8 \% \text { - candidiasis and leukoplakia }\end{array}$ & $\begin{array}{l}\text { "Subjects with and without ART did not show any difference in the } \\
\text { prevalence of periodontal status. Hyperpigmentation was the common } \\
\text { condition found among subjects with ART" }\end{array}$ \\
\hline 18. & Denny et al3 & 2016 & $\begin{array}{l}\text { Man- } \\
\text { galore, } \\
\text { Karna- } \\
\text { taka }\end{array}$ & 108 on ART & $\begin{array}{c}27.8 \% \text { - Candidiasis } \\
42.6 \% \text { - Hyperpigmentation } \\
\text { Linear gingival erythema- } 2.7 \% \\
\text { Kaposi Sarcoma- } 1.9 \% \\
\end{array}$ & $\begin{array}{l}\text { "Oral lesions are considered to be markers of progression of HIV into the } \\
\text { final stage of AIDS. Advent of HAART has shown a significant reduction } \\
\text { in the oral lesions and a better quality of life in patients with HIV" }\end{array}$ \\
\hline 19. & $\begin{array}{l}\text { Usha et } \\
\text { al } 29\end{array}$ & 2017 & $\begin{array}{l}\text { Ban- } \\
\text { galore, } \\
\text { Karna- } \\
\text { taka }\end{array}$ & $\begin{array}{c}600 \text { on HAART } \\
\text { and } 600 \text { not on } \\
\text { HAART but } \\
\text { positive }\end{array}$ & $\begin{array}{l}5.3 \% \text { - oral candidiasis, } \\
1.8 \% \text { - Leukoplakia }\end{array}$ & $\begin{array}{l}\text { "Oral manifestations of HIV infection might serve as good markers for } \\
\text { monitoring, not only restoration of immune function, but also HAART } \\
\text { failure" }\end{array}$ \\
\hline 20. & $\begin{array}{c}\text { Dongade et } \\
\text { al } 30\end{array}$ & 2017 & $\begin{array}{c}\text { Karna- } \\
\text { taka }\end{array}$ & 373 on ART & $\begin{array}{c}64 \% \text { - Oral candidiasis } \\
44.5 \% \text { - oral pigmentation. } \\
\text { 43\%- gingival or periodontal infection, } 33 \% \text { - reduced salivary } \\
\text { Secretion } \\
35 \% \text { - dental caries. } \\
\end{array}$ & $\begin{array}{l}\text { "It was concluded that high incidence of candidiasis may be due to the } \\
\text { habits or history of } \\
\text { tuberculosis, pigmentation, and xerostomia due to the medication." }\end{array}$ \\
\hline 21. & $\begin{array}{l}\text { Muralidha- } \\
\text { ran et al } 16\end{array}$ & 2018 & $\begin{array}{c}\text { Raichur, } \\
\text { Karna- } \\
\text { taka }\end{array}$ & 170 on ART & $\begin{array}{c}\text { 0.58\%- oral candidiasis, } \\
\text { 1.76- Leukoplakia } \\
\text { 25.29- Hyperpigmentation } \\
\text { 45.29\%- Periodontitis } \\
\text { 1.17\%- Ulceration } \\
1.76 \text { - Bald tongue }\end{array}$ & $\begin{array}{l}\text { "There was no association between the oral mucosal conditions and the } \\
\text { age and the adverse habits, such as tobacco and alcohol, CD4 count, and } \\
\text { the time duration of HIV and ART among these patients" }\end{array}$ \\
\hline
\end{tabular}


Table 2. Quality assessment of the studies included in the systematic review.

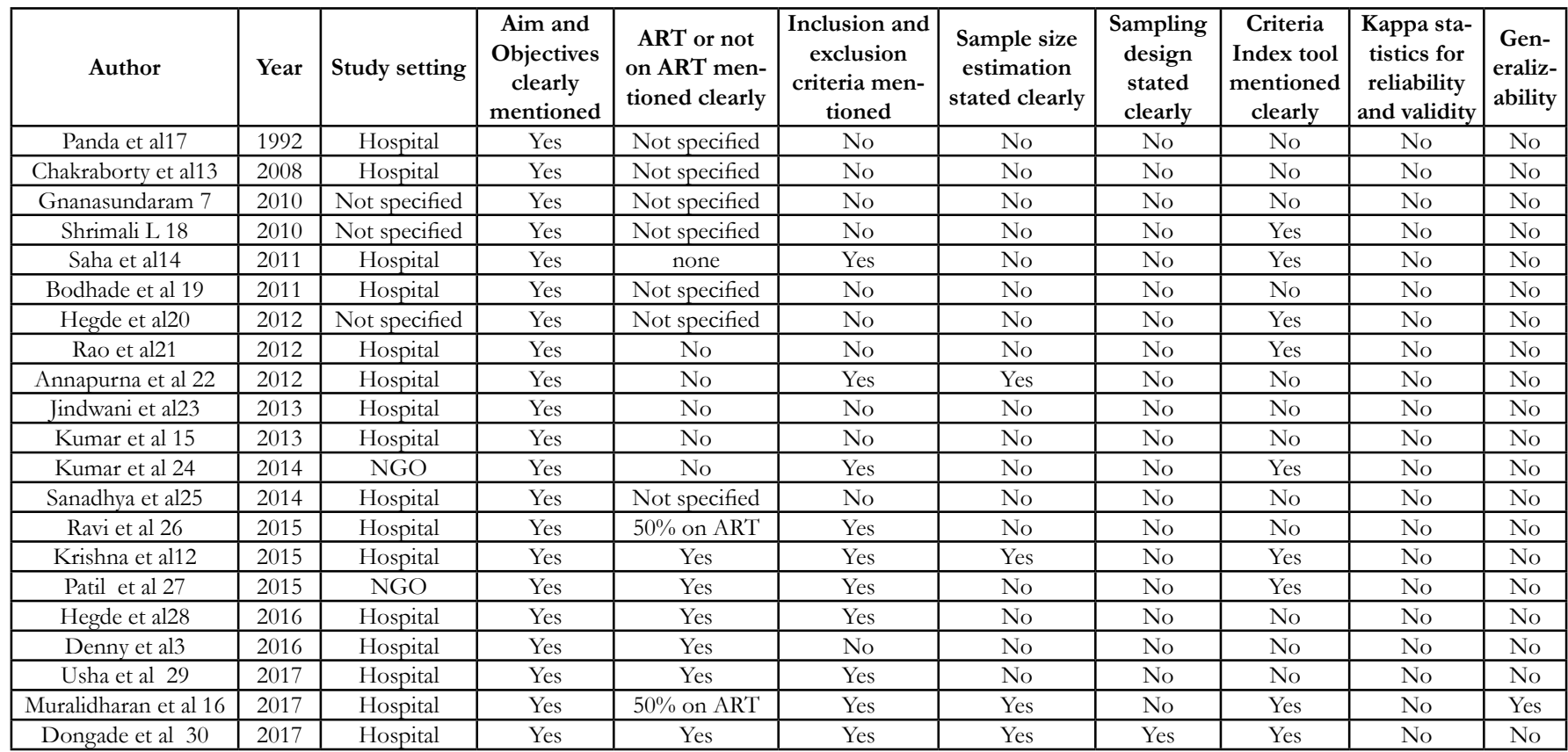

criteria for examination and classification. There is no common consensus or direction in Indian scenario for reporting data in such special groups. Also there is no equitable reporting. Most of the people covered are from the south of India. No stringent sampling technique is followed. Studies have reported if the participants were on ART/ HAART. Unfortunately no studies have been performed on those on second line ART. This is a big lacuna that needs to be addressed. As stated in before, even the ART drugs have ill effects on the oral mucosa, which may manifest in a number of ways. There is no co relation mentioned across the studies related to etiological factors for the conditions. The data presented does not actually represent the current status across the whole of India. It is always possible that some of the participants may be from risky professions like truck drivers, professional sex workers or intra venous drug abuse users. But no report of such profession risk with oral health has been mentioned in any of the articles. No study mentions about oral sex. It is necessary to record such data also because this may be one risk factor for infection transmission. It is unexplored at least in the Indian scenario. Surprisingly, the north east zone hardly finds mention in the oral diseases reporting. The South of India has a multitude of medical and dental institutions that boasts of post -graduation and further studies in dental and allied streams. Hence it is quite possible that this may lead to number of studies from this particular region of India.

The data overall does not serve the purpose of assisting in planning any comprehensive treatment procedures. The arena of managing HIV/AIDS has seen a tremendous change in the last decade. Early diagnosis and prompt treatment is the key for a sustainable institution and continuation of ART. With an improvement in the life and awareness upsurge, as dentists there is always a big challenge to the rising risks related to oral health among the patients. These highly significant and characteristic features are not just to be recorded but also to be tackled. A national data centre for collection of the oral lesions and also a plan to tackle the same is essential. While oral lesions may not be deadly like in case of HIV associated Tuberculosis or Hepatitis infections, they still alter the health slowly and gradually. As the patients undergo regular physical evaluation and drug regime revisions for systemic illness, a similar policy for an oral check-up and preceding treatment is essential. Training and sensitization for health care workers like nursing staff and multi-purpose health workers and counsellors is required for a greater out reach. India is a diverse country with a number of factors that affect health seeking behaviour patterns of the people. In a sensitive case like HIV which is already stigmatized in the society, dentists can play a pivotal role for providing health care as well as basic counselling. This expands our role as well as opens up newer avenues for the dental expertise to explore.

The review has certain limitations. We used only two search engines. Also unreported data related to conference proceedings or from NACO (National AIDS Control Organization) was not conceded. We may have missed a few articles with richer data that did not appear across indexed journals. Further reviews are needed to cover those grey areas of literature too.

\section{Conclusion}

There is a high prevalence of oral candidiasis even among HIV positive patients on ART. More data to compile is available only from South India. Rest regional data is sparse. A range of soft tissue lesions are prevalent and in higher proportions. This can serve as a step to analyse the need to have a nation-wide data and intervention strategies for tackling HIV/ AIDS associated opportunistic infections.

\section{References}

[1]. Shetty S, Kattappagari KK, Hallikeri K, Krishnapilli R. Evaluation of oral lesions in HIV seropositive individuals and its correlation with CD4+ Tlymphocytic count. Journal of Dr. NTR University of Health Sciences. 2016 Apr 1;5(2):123.

[2]. Chaurasia A. CD4+ counts and Oral Lesions in HIV infected/AIDS patientsan Indian Perspective. Juniper online Journal of Case Study. 2017;1(5):1-2.

[3]. Denny CE, Ramapuram J, Bastian TS, Ongole R, Binnal A, Natarajan S. Oral lesions in HIV/AIDS patients on highly active antiretroviral therapy. World Journal of Dentistry. 2016 Apr 1;7(2):95-9. 
[4]. Arirachakaran P, Hanvanich M, Kuysakorn P, Thongprasom K. Antiretroviral Drug-Associated Oral Lichenoid Reaction in HIV Patient: A Case Report. Int J Dent. 2010;2010:291072. Pubmed PMID: 20671969.

[5]. Heron SE, Elahi S. HIV Infection and Compromised Mucosal Immunity: Oral Manifestations and Systemic Inflammation. Front Immunol. 2017 Mar 7;8:241. Pubmed PMID: 28326084.

[6]. Leao JC, Ribeiro CM, Carvalho AA, Frezzini C, Porter S. Oral complications of HIV disease. Clinics (Sao Paulo). 2009 May;64(5):459-70. Pubmed PMID: 19488613.

[7]. Jayakaran TG. The effect of drugs in the oral cavity-A review. Journal of pharmaceutical sciences and research. 2014 Feb 1;6(2):89.

[8]. Max B, Sherer R. Management of the adverse effects of antiretroviral therapy and medication adherence. Clin Infect Dis. 2000 Jun;30 Suppl 2:S96-116. Pubmed PMID: 10860894

[9]. Scully C, Bagan JV. Adverse drug reactions in the orofacial region. Crit Rev Oral Biol Med. 2004 Jul 1;15(4):221-39. Pubmed PMID: 15284187.

[10]. Shrivastava S, Ts B, Singh A, Singh S. ADVERSE EFFECTS OF ANTIRETROVIRAL THERAPY ON ORAL TISSUES IN HIV POSITIVE INDIVIDUALS. Oral \& Maxillofacial Pathology Journal. 2013 Jan 1;4(1).

[11]. Yuan A, Woo SB. Adverse drug events in the oral cavity. Oral Surg Oral Med Oral Pathol Oral Radiol. 2015 Jan;119(1):35-47. Pubmed PMID: 25442252

[12]. Krishna AB, Gannepalli A, Baghirath PV, Khaled S, Shailaja S, Anuradha C. Age-related - oral manifestations and co-morbidities in human immunodeficiency virus-infected/acquired immune deficiency syndrome adults in Hyderabad, India. Indian J Dent Res. 2015 Jul-Aug;26(4):351-5. Pubmed PMID: 26481879.

[13]. Chakraborty N, Mukherjee A, Santra S, Sarkar RN, Banerjee D, Guha SK, et al. Current trends of opportunistic infections among HIV-seropositive patients from Eastern India. Jpn J Infect Dis. 2008 Jan;61(1):49-53. Pubmed PMID: 18219134.

[14]. Saha K, Firdaus R, Santra P, Pal J, Roy A, Bhattacharya MK, et al. Recent pattern of Co-infection amongst HIV seropositive individuals in tertiary care hospital, Kolkata. Virol J. 2011 Mar 14;8:116. Pubmed PMID: 21396133.

[15]. Kumar S, Gowda S, Basavarajaiah. Incidence of Oral candidiasis among HIV infected. Int J Sci Res Publ. 2013;3(12):1-6.

[16]. Muralidharan S, Acharya AK, Margabandhu S, Kalekhan S, Ahsan S, Kulkarni D. Prevalence of Periodontitis and Soft Tissue Lesions among Human Immunodeficiency Virus-positive Patients on Antiretroviral Therapy in Raichur Taluk, Karnataka, India. J Contemp Dent Pract. 2018 Jan 1;19(1):42-46. Pubmed PMID: 29358533.

[17]. Panda S, Kamei G, Pamei M, Sarkar S, Sarkar K, Singh ND, et al. Clinical features of HIV infection in drug users of Manipur. Natl Med J India. 1994 Nov-Dec;7(6):267-9. Pubmed PMID: 7841877.

[18]. Shrimali Lalit. A Study Of Oral Manifestation Of HIV / AIDS. Int J Oral Maxillofac Pathol. 2010;1:8-12.
[19]. Bodhade AS, Ganvir SM, Hazarey VK. Oral manifestations of HIV infection and their correlation with CD4 count. J Oral Sci. 2011 Jun;53(2):20311. Pubmed PMID: 21712625.

[20]. Hegde MN, Hegde ND, Malhotra A. Prevalence of oral lesions in HIV infected adult population of Mangalore, Karnataka, India. Biodiscovery. 2012 Oct 23;4:e8935.

[21]. Rao UK, Ranganathan K, Kumarasamy N. Gender differences in oral lesions among persons with HIV disease in Southern India. J Oral Maxillofac Pathol. 2012 Sep;16(3):388-94. Pubmed PMID: 23248472.

[22]. Annapurna CS, Prince CN, Sivaraj S, Ali IM. Oral manifestations of HIV patients in South Indian population. J Pharm Bioallied Sci. 2012 Aug;4(Suppl 2):S364-8. Pubmed PMID: 23066291.

[23]. Jindwani K, Singh K, Dadlani H. A study of oral lesions among HIV positives in a tertiary care hospital.

[24]. Kumar S, Mishra P, Warhekar S, Airen B, Jain D, Godha S. Oral Health Status and Oromucosal Lesions in Patients Living with HIV/AIDS in India: A Comparative Study. AIDS Res Treat. 2014;2014:480247. Pubmed PMID: 25215229.

[25]. Sanadhya YK, Sanadhya S, Nagarajappa R, Jain S, Aapaliya P, Sharma N. Correlation between oral lesions and opportunistic infections among human immunodeficiency virus - infected individuals in Indian population. Int Marit Health. 2014;65(3):124-30. Pubmed PMID: 25471161.

[26]. Ravi JR, Rao TR. Estimation of prevalence of periodontal disease and oral lesions and their relation to CD4 counts in HIV seropositive patients on antiretroviral therapy regimen reporting at District General Hospital, Raichur. J Indian Soc Periodontol. 2015 Jul-Aug;19(4):435-9. Pubmed PMID: 26392694.

[27]. Patil N, Chaurasia VR, Babaji P, Ramesh D, Jhamb K, Sharma AM. The effect of highly active antiretroviral therapy on the prevalence of oral manifestation in human immunodeficiency virus-infected patients in Karnataka, India. Eur J Dent. 2015 Jan-Mar;9(1):47-52. Pubmed PMID: 25713484.

[28]. Hegde V, Shetty PJ, Alva S, Chengappa SK. Assessment of dental caries experience, periodontal status, and oral mucosal lesions among human immunodeficiency virus seropositives with and without antiretroviral therapy: A cross-sectional study. Journal of Indian Association of Public Health Dentistry. 2016 Jan 1;14(1):46.

[29]. Usha H, Naik B. Comparison of oral lesions in HIV patients with and without highly active antiretroviral therapy visiting government hospitals in Bengaluru city. J Evid Based Med Healthc. 2017;4(20):1141-1147.

[30]. Dongade S, Sermadi ZM, Manjunath R, Priyadarshini C, Jayapala MS. Prevalence of oral manifestations among hiv-positive patients undergoing antiretroviral treatment visiting Chamarajanagar district hospital: A crosssectional study. Journal of Indian Academy of Oral Medicine and Radiology. 2017 Oct $1 ; 29(4): 288$ 